\title{
3-Hydroxy-3-Methylglutaryl-Coenzyme A Reductase Inhibitors Attenuate $\beta$-Amyloid-Induced Microglial Inflammatory Responses
}

\author{
Andrew Cordle and Gary Landreth \\ Alzheimer Research Laboratory, Department of Neurosciences, Case Western Reserve University School of Medicine, Cleveland, Ohio 44106
}

\begin{abstract}
Alzheimer's disease (AD) is characterized by extracellular deposits of fibrillar $\beta$-amyloid $(\mathrm{A} \beta)$ in the brain, a fulminant microglialmediated inflammatory reaction, and neuronal death. The use of 3-hydroxy-3-methylglutaryl-coenzyme A reductase inhibitors (statins) is associated with a reduced risk of $\mathrm{AD}$, which has been attributed to the cholesterol-lowering actions of these drugs. Statins have been reported recently to have anti-inflammatory actions in addition to their classic lipid-lowering effects. We report that statins robustly inhibited the $\mathrm{A} \beta$-stimulated expression of interleukin- $1 \beta$ and inducible nitric oxide synthase and the production of nitric oxide by microglia and monocytes. Statin treatment also blocked the rac1-dependent activation of NADPH oxidase and superoxide production. The anti-inflammatory actions of the statins were attributable to their ability to reduce the levels of isoprenyl intermediates in the cholesterol biosynthetic pathway. The effect of statins could not be reversed by exogenous cholesterol supplementation, indicating that the anti-inflammatory actions are distinct from their cholesterol-lowering actions. The addition of the isoprenyl precursors, mevalonic acid, and geranylgeranyl pyrophosphate (GGpp) attenuated the statin-mediated downregulation of inflammatory markers. Prevention of protein isoprenylation by the GGpp transferase inhibitor (GGTI-286) or inhibition of Rho-family function with Clostridium difficile Toxin A blocked the inflammatory response similar to the effect of statin treatment. We argue that the statin-mediated decrease in AD risk arises from their pleiotropic actions, effecting a reduction in neuronal $\mathrm{A} \beta$ production and microglia-directed inflammation.
\end{abstract}

Key words: Alzheimer; $\beta$-amyloid; inflammation; HMG-CoA reductase inhibitor; microglia; NSAIDs

\section{Introduction}

Alzheimer's disease (AD) is a progressive neurodegenerative condition that is characterized by extraneuronal deposits of $\beta$-amyloid $(\mathrm{A} \beta)$ fibrils $(\mathrm{fA} \beta)$ and intraneuronal accumulations of hyperphosphorylated tau. $\mathrm{AD}$ has a significant inflammatory component evidenced by abundant plaque-associated microglia that exhibit a reactive phenotype (Akiyama and McGeer, 1990; Masliah et al., 1991; Peress et al., 1993; Akiyama et al., 2000). The activated microglia release a diverse array of proinflammatory molecules that act to exacerbate the disease process and contribute to neuronal death (Combs et al., 2000, 2001b; Yates et al., 2000).

Epidemiological studies suggest that treatment with cholesterol-lowering statins reduces the risk of developing AD (Jick et al., 2000; Wolozin et al., 2000; Rockwood et al., 2002). Statins reduce plasma cholesterol levels by inhibiting the ratelimiting enzyme in the cholesterol biosynthetic pathway, 3-hydroxy-3-methylglutaryl-coenzyme A (HMG-CoA) reductase, which prevents de novo synthesis of cholesterol (Endo, 1992;

Received June 25, 2004; revised Nov. 16, 2004; accepted Nov. 18, 2004.

This work was supported by National Institutes of Health Grant AG 16704 and in part by Case Western Reserve University Medical Scientist Training Program Grant T32 GM07250. We thank the Blanchett Rockefeller Foundation and the Coins for Alzheimer's Research Trust Fund of Rotary International for generous support of our work.

Correspondence should be addressed to Gary Landreth, Alzheimer Research Laboratory, E504, Case Western Reserve University School of Medicine, 10900 Euclid Avenue, Cleveland, 0H 44106. E-mail: gel2@cwru.edu. DOI:10.1523/JNEUROSCI.2544-04.2005

Copyright $\odot 2005$ Society for Neuroscience $\quad$ 0270-6474/05/250299-09\$15.00/0
Tobert, 2003). Statin treatment has been shown to reduce $\mathrm{A} \beta$ production both in vitro and in animal models (Fassbender et al., 2001; Petanceska et al., 2002; Parvathy et al., 2004). Recent prospective studies indicate that statin use reduces soluble $\mathrm{A} \beta$ levels in the brain and may improve cognitive function (Buxbaum et al., 2002; Simons et al., 2002; Sjogren et al., 2003; Caballero and Nahata, 2004). These effects are thought to result from reduction in amyloidgenic amyloid precursor protein (APP) processing owing to the sensitivity of $\beta$ and $\gamma$ secretases to neuronal membrane cholesterol content (Simons et al., 1998; Kojro et al., 2001; Burns and Duff, 2002; Wahrle et al., 2002; Wolozin, 2002; Cordy et al., 2003; Puglielli et al., 2003).

Statins also exhibit robust anti-inflammatory effects (Pahan et al., 1997; Bellosta et al., 1998; Ortego et al., 1999; Grip et al., 2000, 2002; Wong et al., 2001; Delbosc et al., 2002; Youssef et al., 2002; Zelvyte et al., 2002; Nath et al., 2004). Many of the antiinflammatory actions of statins are postulated to arise from a reduction of isoprenoid intermediates in the cholesterol biosynthetic pathway (Liao and Laufs, 2004). The isoprenoids geranylgeranyl pyrophosphate (GGpp) and farnesyl pyrophosphate (Fpp) are added to the $\mathrm{C}$ termini of small $\mathrm{G}$-proteins facilitating specific interactions with cytoplasmic regulators, cellular membranes, and effectors (Zhang and Casey, 1996). The small G-proteins are essential elements in inflammatory signaling cascades, and thus statin blockade of small G-protein lipid modification acts to functionally inhibit these pathways (Liao, 2002).

The ability of statins to reduce AD risk may arise, in part, 
through inhibition of microglial-induced inflammation. We report the ability of HMG-CoA reductase inhibitors to downregulate the inflammatory response of THP-1 monocytes and BV-2 microglial cells to $A \beta$ by inhibiting the function of Rho-family small G-proteins. Statin-mediated blockade of HMG-CoA conversion to mevalonate decreases the pools of isoprenoids, inhibits the lipid modification of Rho-family members, and prevents small G-protein-mediated activation of downstream proinflammatory signaling pathways. The beneficial effects of statins are likely derived from both reduced neuronal $\mathrm{A} \beta$ production and suppression of microglial inflammatory responses.

\section{Materials and Methods}

Materials and reagents. Lipopolysaccharide (LPS), Escherichia coli K12, and D31m4 (Re) were purchased from List Biological Laboratories (Campbell, CA). Stock solutions were prepared with sterile distilled water. $\mathrm{A} \beta$ peptides $\left(\mathrm{A} \beta_{25-35}\right.$ and $\left.\mathrm{A} \beta_{1-42}\right)$, purchased from American Peptide Company (Sunnyvale, $\mathrm{CA}$ ), were dissolved in sterile water at a concentration of $2 \mathrm{~mm}$ and then incubated for $5 \mathrm{~d}$ at $37^{\circ} \mathrm{C}$ to induce fibril formation. Simvastatin and lovastatin were obtained from Calbiochem (La Jolla, CA) and prepared following the instructions of the manufacturer. Briefly, the statin was converted to its active form by dissolving it in absolute ethanol followed by the addition of $1 \mathrm{~N} \mathrm{NaOH}$. This solution was stored at $-20^{\circ} \mathrm{C}$ until use. Immediately before use, the statin solution was neutralized ( $\mathrm{pH} 7.2)$ with $1 \mathrm{~N} \mathrm{HCl}$. Geranylgeranyl pyrophosphate triammonium salt and farnesyl pyrophosphate triammonium salt were purchased from Biomol (Plymouth Meeting, PA) and dissolved in 70\% ethanol. The GGpp transferase inhibitor (GGTI-286) and the Fpp transferase inhibitor (FTI-277), were purchased from Calbiochem and were reconstituted in DMSO. Clostridium difficile Toxin A was purchased from Calbiochem. Nitroblue tetrazolium chloride (NBT) was purchased from Roche (Basel, Switzerland). Griess Reagent was purchased from Sigma (St. Louis, MO). The Amplex Red Cholesterol Assay kit was purchased from Molecular Probes (Eugene, OR). Antibodies to interleukin- $1 \beta$ (IL-1 $\beta$ ) (3ZD), Rac (05-389), inducible nitric oxide synthase (iNOS) (Sc7271), and extracellular signal-regulated kinase 2 (ERK2) (Sc-154) were obtained from the National Cancer Institute Biological Research Branch Preclinical Repository (Bethesda, MD), Upstate Biotechnology (Waltham, MA), and Santa Cruz Biotechnology (Santa Cruz, CA), respectively.

Cell culture. Human THP-1 monocytes from American Type Culture Collection (Manassas, VA) were cultured in RPMI 1640 (Whittaker Bioproducts, Walkersville, $\mathrm{MD}$ ) at $37^{\circ} \mathrm{C}$ and $5 \% \mathrm{CO}_{2}$. RPMI was supplemented with $10 \%$ heat-inactivated fetal bovine serum (FBS) (SH30397.03; Hyclone, Logan, UT), $50 \mu \mathrm{M}$ 2-mercaptoethanol, and 15 $\mu \mathrm{g} / \mathrm{ml}$ gentamycin. The RPMI serum concentration was lowered to $2 \%$ at the beginning of the experiments. Mouse BV-2 microglia were maintained in DMEM at $37^{\circ} \mathrm{C}$ and $5 \% \mathrm{CO}_{2}$. The DMEM was supplemented with $10 \%$ fetal bovine serum, $50 \mu \mathrm{M} 2$-mercaptoethanol, and $15 \mu \mathrm{g} / \mathrm{ml}$ gentamycin.

IL- $1 \beta$ and iNOS Western blots. THP- 1 cells $\left(3 \times 10^{6}\right.$ cells $)$ were plated into 24 -well plates in a total volume of $500 \mu$ l of $2 \%$ heat-inactivated FBS-RPMI plus 5 mм HEPES, pH 7.2. Cells were then pretreated with the indicated compounds (simvastatin, lovastatin, GGpp, Fpp, GTI-286, FTI-277, and Toxin A) for either 6 or $18 \mathrm{~h}$. After the pretreatment period, the cells were stimulated with fibrillar $\mathrm{A} \beta_{25-35}$, LPS, fibrillar $\mathrm{A} \beta_{25-35}$ and LPS, or fibrillar $A \beta_{1-42}$ for 6 or $18 \mathrm{~h}$. Cells were collected and lysed with radioimmunoprecipitation assay (RIPA) buffer (1\% Triton X-100, 20 mm Tris, pH 7.5, $100 \mathrm{~mm} \mathrm{NaCl}, 40 \mathrm{~mm} \mathrm{NaF}, 0.2 \%$ SDS, 0.5\% deoxycholate, $1 \mathrm{~mm}$ EDTA, $1 \mathrm{~mm}$ EGTA, and $\left.1 \mathrm{~mm} \mathrm{Na}_{3} \mathrm{VO}_{4}\right)$. Lysates were sonicated for $10 \mathrm{~s}$ on ice and cleared by centrifugation $(16,000 \times g, 15$ $\left.\min , 4^{\circ} \mathrm{C}\right)$. Protein concentration was determined by the Bradford method (Bradford, 1976). The samples $(50 \mu \mathrm{g})$ were separated on $12 \%$ SDS-PAGE gels and transferred to polyvinylidene fluoride membranes. After blocking in a 5\% milk solution, blots were incubated overnight at $4^{\circ} \mathrm{C}$ with anti-IL- $1 \beta$ antibodies (1:1000). iNOS blots were blocked in a $5 \%$ bovine serum albumin solution and incubated with anti-iNOS antibodies at a dilution of 1:1000. Bands were visualized by incubation of blots with anti-mouse HRP-conjugated secondary antibodies (1:1000; 90 min at room temperature) and visualized by enhanced chemiluminescence (Pierce, Rockford, IL). Blots were stripped by incubation in stripping buffer (62.5 mu Tris, pH 6.8, $100 \mathrm{~mm} \beta$-mercaptoethanol, and 2\% SDS) for $30 \mathrm{~min}$ at $50^{\circ} \mathrm{C}$. Protein loading was evaluated by reprobing blots with an anti-ERK2 (1:3000) antibody. Band intensities were quantified using a Bio-Rad (Hercules, CA) Versadoc image analysis hardware/ software package.

NO assay. BV- 2 cells $\left(5 \times 10^{5}\right.$ cells $)$ were plated in 24 -well plates in a total volume of $500 \mu \mathrm{l}$ of $10 \%$ FBS-DMEM plus 5 mM HEPES, pH 7.2. Cells were pretreated with simvastatin for $6 \mathrm{~h}$ and then stimulated with $\mathrm{A} \beta_{25-35}$ and LPS for $18 \mathrm{~h}$. One hundred microliters of cell medium were collected and assayed for NO levels with the Griess Reagent (Green et al., 1982). The release of NO was determined indirectly by measuring the absorbance at $540 \mathrm{~nm}$. Duplicate measurements were obtained for each sample. The remainder of the sample $(\sim 300 \mu \mathrm{l})$ was used for an MTT assay to normalize the Griess values for cell viability and number. Briefly, $30 \mu \mathrm{l}$ of MTT solution (1:1000 dilution) was mixed with the sample. This mixture was incubated for $2 \mathrm{~h}$ at $37^{\circ} \mathrm{C}, 5 \% \mathrm{CO}_{2}$. After incubation, the cell medium was removed, and cells were lysed by the addition of $500 \mu \mathrm{l}$ of DMSO and rocking at room temperature for $10 \mathrm{~min}$ in the dark. Two hundred microliters of lysate were transferred to a 96-well plate, and the absorbance at $550 \mathrm{~nm}$ was measured.

Reactive oxygen species assay. BV- 2 cells $\left(3.5 \times 10^{6}\right.$ cells $)$ were added to 6 -well plates in a total volume of $2 \mathrm{ml}$ of $10 \%$ FBS-DMEM plus $5 \mathrm{~mm}$ HEPES, pH 7.2. Cells were pretreated with various concentrations of simvastatin for $18 \mathrm{~h}$ at $37^{\circ} \mathrm{C}, 5 \% \mathrm{CO}_{2}$. After the pretreatment period, the cells were removed from the wells by trypsin treatment and collected. Cells were resuspended in serum-free DMEM containing NBT (final concentration, $1 \mathrm{mg} / \mathrm{ml}$ ). A $\beta_{25-35}$ plus LPS were added to the cell solution, and the mixture was incubated for $30 \mathrm{~min}$ at $37^{\circ} \mathrm{C}, 5 \% \mathrm{CO}_{2}$. Cells were collected and lysed using RIPA buffer and brief sonication (10 s). Aliquots of the samples were added to 96 -well plates, and NBT reduction was measured by absorbance at $550 \mathrm{~nm}$ in triplicate.

Cholesterol measurement. THP- 1 cells $\left(5 \times 10^{6}\right.$ cells $)$ were plated into 24 -well plates in a total volume of $500 \mu \mathrm{l}$ of $2 \%$ heat-inactivated FBSRPMI plus $5 \mathrm{~mm}$ HEPES, pH 7.2. Cells were treated with increasing concentrations of simvastatin for $24 \mathrm{~h}$. Cholesterol concentrations were determined using a Molecular Probes Amplex Red cholesterol assay kit. Briefly, cells were lysed and incubated with cholesterol esterase, cholesterol oxidase, horseradish peroxidase, and Amplex Red. Under these conditions, all forms of cholesterol contribute to $\mathrm{H}_{2} \mathrm{O}_{2}$ production, which subsequently converts Amplex Red to resorufin in the presence of HRP. The amount of cholesterol was determined indirectly by measuring resorufin absorbance at $560 \mathrm{~nm}$.

Western blot quantification and statistical analysis. The density of IL-1 $\beta$ or iNOS Western blot bands was determined using a Bio-Rad Versadoc image analysis system. Band densities were normalized for protein loading by comparison with Erk2 band densities. Two to three experiments were pooled to create graphical representations. Mean values \pm SEM were calculated, and statistical differences were determined using a oneway ANOVA. A Tukey-Kramer post test was used to determine $p$ values.

\section{Results}

\section{Statins inhibit the production of IL- $1 \boldsymbol{\beta}$ after $\mathrm{A} \boldsymbol{\beta}$ exposure}

We have shown previously that exposure of primary microglia and THP-1 monocytes to fibrillar $\beta$-amyloid peptides resulted in the production and secretion of various proinflammatory cytokines, including IL- $1 \alpha$, IL- $1 \beta$, IL- 6 , and tumor necrosis factor $\alpha$ $(\mathrm{TNF} \alpha)$, and the production of reactive oxygen species (ROS) and nitrogen species (McDonald et al., 1997; Combs et al., 1999, 2000, 2001a; Bamberger et al., 2003). These studies have demonstrated that microglia and monocytes interact and respond to fibrillar forms of $\mathrm{A} \beta_{1-40}, \mathrm{~A} \beta_{1-42}$, or $\mathrm{A} \beta_{25-35}$ with similar efficiency. We investigated whether the HMG-CoA reductase inhibitors affected the ability of these cells to mount a proinflammatory response to fibrillar $\mathrm{A} \beta$. We tested the ability of simvastatin to downregulate the production of IL- $1 \beta$ after stimulation with 
A

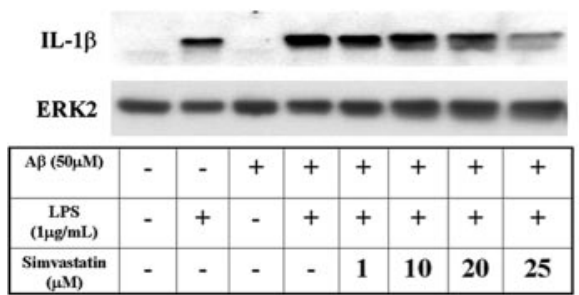

B

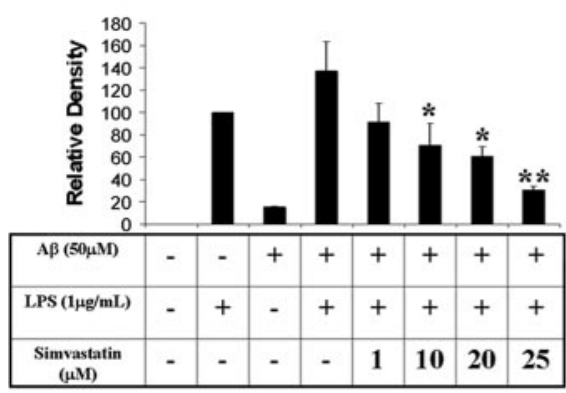

$\mathrm{E}$

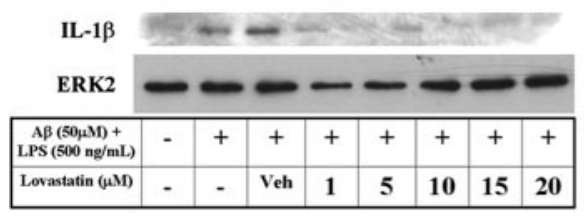

C

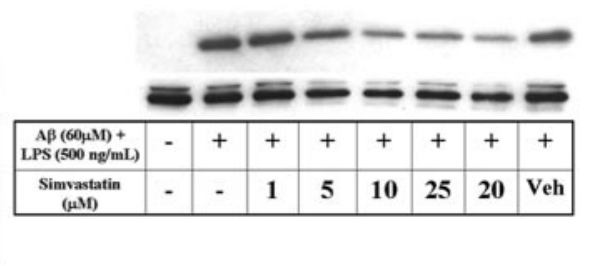

$\mathrm{D}$

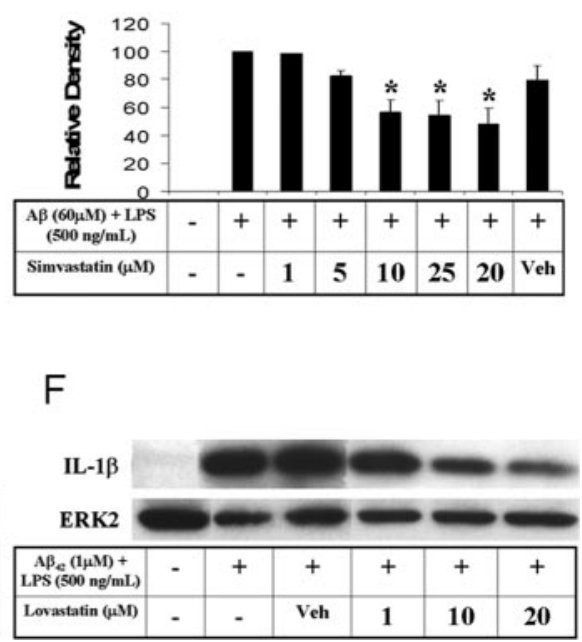

Figure 1. Statins attenuate IL-1 $\beta$ induction after $A \beta$ stimulation. $A$, THP- 1 cells $\left(3 \times 10^{6} /\right.$ condition) were pretreated with increasing concentration of simvastatin for $6 \mathrm{~h}$. After pretreatment, $A \beta_{25-35}(50 \mu \mathrm{m})$, LPS $(1 \mu \mathrm{g} / \mathrm{ml})$, or $A \beta_{25-35}$ and LPS were added to the cells and incubated for $18 \mathrm{~h}$. Cell lysates were separated by Western blotting and probed with anti-IL-1 $\beta$ antibodies. Blots were stripped and reprobed with anti-Erk2 antibodies to monitor protein loading. $B$, Quantification of pooled experiments was performed ( $n=3 ;{ }^{*} p<0.05,{ }^{* *} p<0.001$ compared with $A \beta_{25-35}$ plus LPS). C, THP-1 cells ( $3 \times 10^{6} /$ condition) were pretreated with increasing concentration of simvastatin for $18 \mathrm{~h}$. After pretreatment, $A \beta_{25-35}(60 \mu \mathrm{M})$ and LPS $(500 \mathrm{ng} / \mathrm{ml})$ were added to the cells and incubated for $6 \mathrm{~h}$. Cell lysates were separated by Western blotting and probed with anti-IL-1 $\beta$ antibodies. Blots were stripped and reprobed with anti-Erk2 antibodies to monitor protein loading. D, Quantification of pooled experiments was performed ( $n=2$; ${ }^{*} p<0.05$ compared with $A \beta_{25-35}$ plus LPS). E, THP-1 cells $\left(3 \times 10^{6} /\right.$ condition) were pretreated with increasing concentration of lovastatin for $18 \mathrm{~h}$. After pretreatment, $A \beta_{25-35}(50 \mu \mathrm{m})$ and $L P S(500 \mathrm{ng} / \mathrm{ml})$ were added to the cells and incubated for $6 \mathrm{~h}$. Cell lysates were separated by Western blotting and probed with anti-IL-1 $\beta$ antibodies. Blots were stripped and reprobed with anti-Erk2 antibodies to monitor protein loading. F, THP-1 cells $\left(3 \times 10^{6} \%\right.$ condition) were pretreated with increasing concentration of lovastatin for $18 \mathrm{~h}$. After pretreatment, $A \beta_{1-42}(1 \mu \mathrm{M})$ and LPS $(500 \mathrm{ng} / \mathrm{ml})$ were added to the cells and incubated for $6 \mathrm{~h}$. Cell lysates were separated by Western blotting and probed with anti-IL-1 $\beta$ antibodies. Blots were stripped and reprobed with anti-Erk2 antibodies to monitor protein loading. Veh, Vehicle.

A $\beta$. THP-1 monocytes were pretreated with increasing concentrations of simvastatin $(1-25 \mu \mathrm{M})$ for $6 \mathrm{~h}$ (Fig. $1 A, B)$ or $18 \mathrm{~h}$ (Fig. $1 C, D)$. IL- $1 \beta$ was induced by incubation with $\mathrm{A} \beta_{25-35}(50 \mu \mathrm{M})$, LPS $(1 \mu \mathrm{g} / \mathrm{ml}$ ), or both for $18 \mathrm{~h}$ (Fig. $1 A, B)$ or $6 \mathrm{~h}$ (Fig. $1 C, D)$. Simvastatin treatment attenuated IL- $1 \beta$ expression in a dosedependent manner (Fig. $1 A-D$ ). This effect was not attributable to a general reduction in protein synthesis as demonstrated by the unchanged levels of Erk2. Furthermore, the statins did not affect cellular viability, which was monitored by MTT assays (data not shown). Figure 1, $A$ and $B$, also illustrates the synergistic effects observed with the combinatorial stimulation with A $\beta$ and LPS. We observed a similar effect with lovastatin, providing evidence that the suppression of IL- $1 \beta$ expression was reflective of the action of this class of drugs (Fig. $1 E$ ). We also observed that stimulation of IL- $1 \beta$ production by exposure of the cells to fibrillar $\mathrm{A} \beta_{1-42}$ (as reported previously) can be attenuated by statin pretreatment (Fig. $1 F)$.
Simvastatin inhibits the induction and activity of iNOS after $A \beta$ exposure Microglial activation is accompanied by the induction of iNOS with the subsequent production of nitric oxide (Weldon et al., 1998; Combs et al., 2001b; Giovannini et al., 2002). We tested whether statin treatment could suppress the expression of iNOS. BV-2 microglia were pretreated with increasing concentrations of simvastatin for $6 \mathrm{~h}$ followed by an $18 \mathrm{~h}$ stimulation with $A \beta / L P S$. We observed the dosedependent ability of simvastatin to downregulate the $A \beta / L P S-m e d i a t e d$ induction of iNOS by $>80 \%$ (Fig. $2 A, B$ ). There was a parallel simvastatin-mediated reduction in NO levels (Fig. 2C).

\section{Simvastatin inhibits the production of reactive oxygen species after $\mathrm{A} \boldsymbol{\beta}$ exposure}

$\mathrm{A} \beta$ stimulation of microglia or monocytes leads to the activation of NADPH oxidase and the production of reactive oxygen species, which are ultimately responsible for much of the cellular oxidative damage (McDonald et al., 1997; Bamberger et al., 2003). We tested whether simvastatin could reduce the generation of superoxide radicals elicited by treatment of the cells with $A \beta / L P S$. BV- 2 microglia were pretreated with increasing concentrations of simvastatin for $18 \mathrm{~h}$ and then incubated with A $\beta /$ LPS (Fig. 3). Simvastatin treatment dramatically inhibited NADPH oxidase activation and ROS production. The suppression of ROS generation was quite sensitive to simvastatin, because drug concentrations as low as $1 \mu \mathrm{M}$ were found to inhibit this response.

\section{Blockade of cholesterol biosynthesis by simvastatin does not account for its anti-inflammatory effects}

The primary effect of HMG-CoA reductase inhibitors is to block the synthesis of cholesterol, but it also reduces the cellular pools of all the lipid intermediates in the biosynthetic pathway. We wanted to ascertain whether the anti-inflammatory actions of the statins were a consequence of drug-induced reduction of cellular cholesterol levels. Cholesterol levels were measured in THP-1 cells after treatment with simvastatin for $24 \mathrm{~h}$. Under our experimental conditions, cholesterol levels were unchanged after statin treatment (data not shown). These observations were in agreement with published results that indicate cholesterol-free medium must be used to decrease cellular levels of cholesterol with statin treatment (Kojro et al., 2001). To further investigate the role of cholesterol, THP-1 cells were pretreated for $6 \mathrm{~h}$ with simvastatin $(25 \mu \mathrm{M})$ with or without the addition of increasing concentrations of exogenous cholesterol $(25-50 \mu \mathrm{M})$. After pretreatment, cells were exposed to A $\beta /$ LPS for $18 \mathrm{~h}$. As shown in Figure 4, $A$ and $B$, cholesterol supplementation did not attenuate the simvastatin-mediated reduction of IL-1 $\beta$. These results sug- 


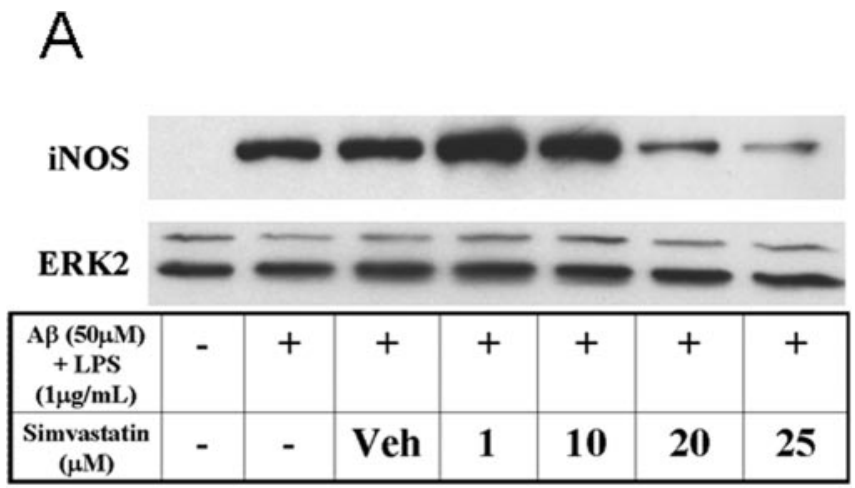

$\mathrm{B}$
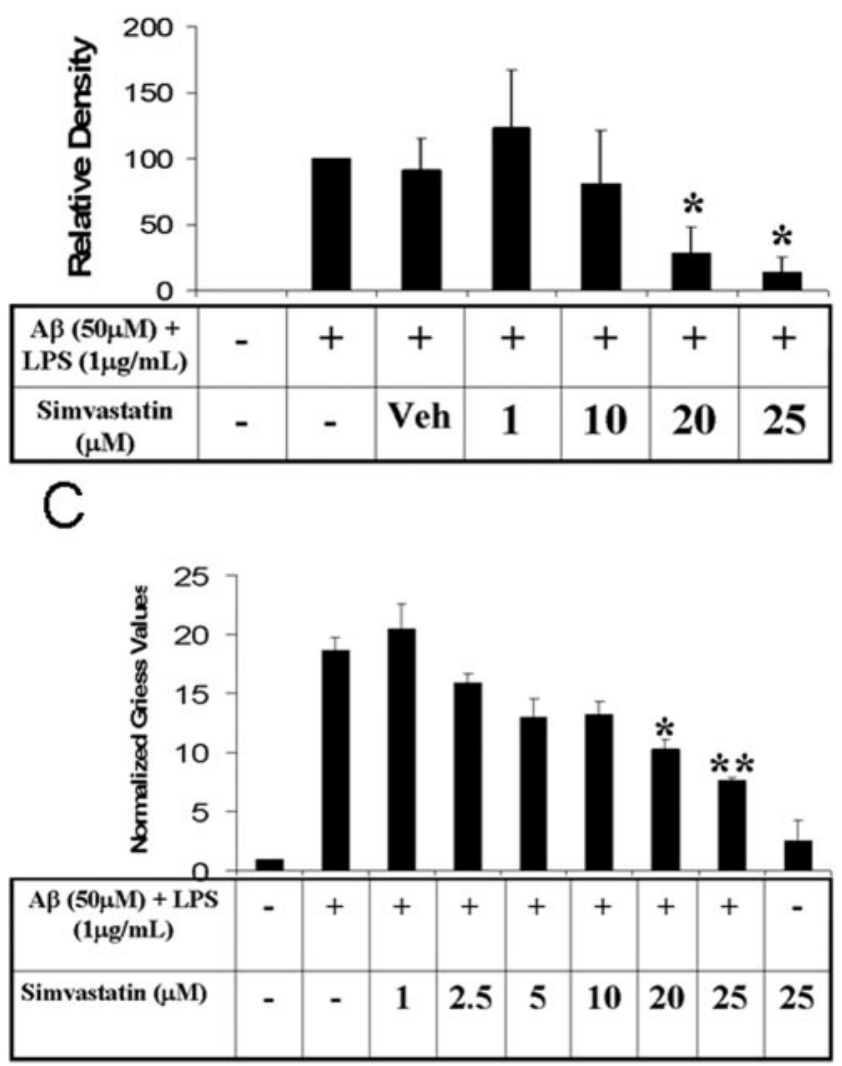

Figure 2. Statins attenuate iNOS expression and activity after $\mathrm{A} \beta$ stimulation. $A, \mathrm{BV}-2$ cells $\left(1 \times 10^{6} /\right.$ condition) were pretreated with increasing concentration of simvastatin for $6 \mathrm{~h}$. After pretreatment, $A \beta_{25-35}(50 \mu \mathrm{m})$ and LPS $(1 \mu \mathrm{g} / \mathrm{ml})$ were added to the cells and incubated for $18 \mathrm{~h}$. Cell lysates were separated by Western blotting and probed with anti-iNOS antibodies. Blots were stripped and reprobed with anti-Erk2 antibodies to monitor protein loading. $B$, Quantification of pooled experiments was performed $\left(n=3\right.$; ${ }^{*} p<0.05$ compared with $A \beta$ plus LPS). C, BV-2 cells ( $5 \times 10^{5} /$ condition) were pretreated with increasing concentration of simvastatin for $6 \mathrm{~h}$. After pretreatment, $A \beta_{25-35}(50 \mu \mathrm{m})$ and $\mathrm{LPS}(1 \mu \mathrm{g} / \mathrm{ml})$ were added to the cells and incubated for $18 \mathrm{~h}$. N0 production was measured by Griess reagent and normalized by MTT assay $\left(n=3 ;{ }^{*} p<0.01,{ }^{* *} p<0.001\right.$ compared with A $\beta$ plus LPS). Veh, Vehicle.

gested that the anti-inflammatory actions of simvastatin were independent of cellular cholesterol levels.

Supplementation with lipid intermediates of the cholesterol biosynthetic pathway attenuates the anti-inflammatory actions of simvastatin

We hypothesized that if other lipid intermediates in this pathway were involved with the anti-inflammatory actions of simvastatin,

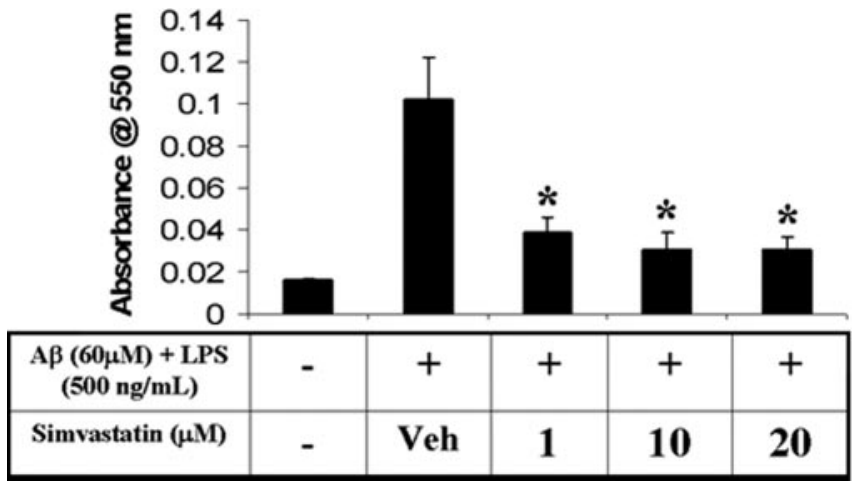

Figure 3. Statins attenuate reactive oxygen species production after $A \beta$ stimulation. BV-2 cells $\left(3.5 \times 10^{6} /\right.$ condition) were pretreated with increasing concentration of simvastatin $(1-20 \mu \mathrm{m})$ for $18 \mathrm{~h}$. After pretreatment, $A \beta_{25-35}(60 \mu \mathrm{m})$ and LPS $(500 \mathrm{ng} / \mathrm{ml})$ were added to the cells and incubated for $30 \mathrm{~min}$. Production of ROS was determined by NBT assay ( $n=2$; ${ }^{*} p<0.001$ compared with $A \beta$ plus LPS). Veh, Vehicle.

they could be identified by supplying these molecules exogenously. The direct product of HMG-CoA reductase, mevalonic acid, was added to the cells in the presence of simvastatin for $6 \mathrm{~h}$. The cells were then exposed to A $\beta /$ LPS for $18 \mathrm{~h}$, and IL- $1 \beta$ levels were measured. The addition of mevalonic acid, attenuated the simvastatin, induced reduction of IL- $1 \beta$ (Fig. $4 C, D$ ). These results, coupled with the cholesterol data, indicate that the reduction of molecular intermediates downstream of mevalonic acid, but not cholesterol, is responsible for the anti-inflammatory actions of simvastatin.

We investigated the involvement of the cholesterol biosynthetic intermediates GGpp and Fpp in the anti-inflammatory actions of statins. Fpp serves as a branch point in the metabolic pathway. Although it can be converted to squalene and then on to cholesterol, it can also be converted to GGpp. The isoprenoids Fpp and GGpp serve as substrates for lipid modification of various signaling molecules, including many members of the ras superfamily of small G-proteins. These isoprenyl modifications are necessary for proper cellular localization and function (Zhang and Casey, 1996). We hypothesized that the anti-inflammatory actions of statins could be explained by decreasing the pools of Fpp and GGpp, which would subsequently disrupt G-protein function and downstream intracellular signaling cascades.

THP- 1 cells were pretreated with simvastatin in the presence or absence of increasing concentrations of GGpp for $6 \mathrm{~h}$. Subsequently, the cells were exposed to A $\beta /$ LPS for $18 \mathrm{~h}$, and IL- $1 \beta$ protein levels were quantified. The addition of GGpp attenuated the decrease in IL- $1 \beta$ levels caused by simvastatin (Fig. $5 A, B$ ). Supplementation with Fpp did not significantly reverse the effects of simvastatin (Fig. 5C,D). These experiments provided clear evidence that the anti-inflammatory actions of statins are mediated by downregulation of the lipid intermediates in the cholesterol biosynthetic pathway. Specifically, this suggests that inhibiting isoprenylation of various proteins by decreasing the pools of GGpp is the mechanism by which statins block the inflammatory response.

\section{Inhibition of isoprenylation attenuates the production of IL-1 $\boldsymbol{\beta}$ after $\mathrm{A} \boldsymbol{\beta}$ exposure}

We wanted to directly test whether statin-mediated downregulation of protein isoprenylation was responsible for the attenuation in the IL- $1 \beta$ response and hypothesized that a direct inhibition of isoprenylation should mimic the effects of simvastatin. The en- 
A

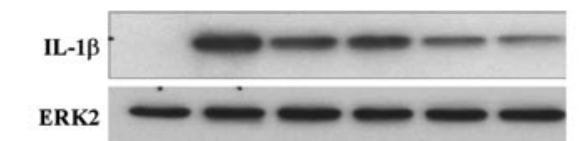

\begin{tabular}{|c|c|c|c|c|c|c|}
\hline $\begin{array}{c}\mathrm{A \beta}(50 \mu \mathrm{M})+ \\
\mathrm{LPS}(1 \mu \mathrm{g} / \mathrm{mL})\end{array}$ & - & + & + & + & + & + \\
\hline $\begin{array}{c}\text { Simvastatin } \\
(\mu \mathrm{M})\end{array}$ & - & - & $\mathbf{2 5}$ & $\mathbf{2 5}$ & $\mathbf{2 5}$ & $\mathbf{2 5}$ \\
\hline $\begin{array}{c}\text { Cholesterol } \\
(\mu \mathrm{M})\end{array}$ & - & - & - & Veh & $\mathbf{2 5}$ & $\mathbf{5 0}$ \\
\hline
\end{tabular}

B

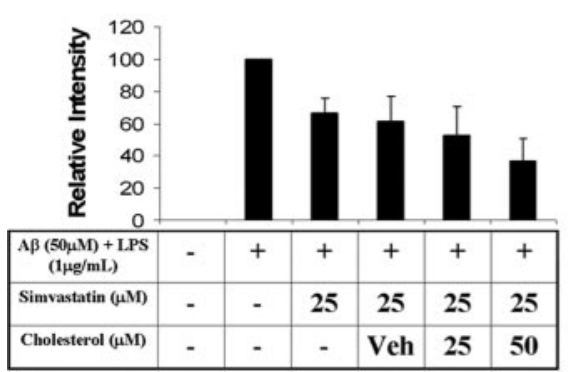

C

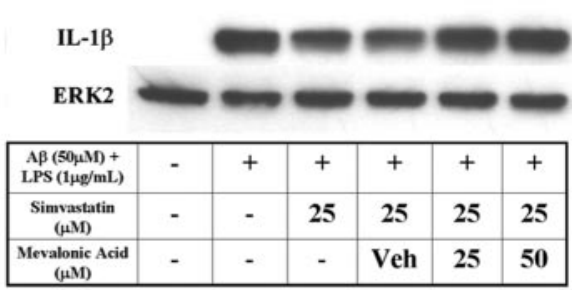

D

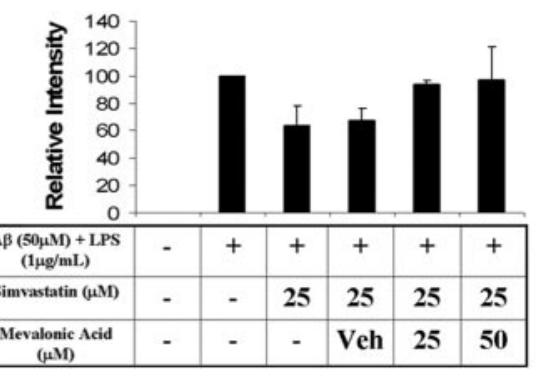

Figure 4. Mevalonic acid, but not cholesterol, reverses the anti-inflammatory effects of statins. A, C, THP-1 cells $\left(3 \times 10^{6} \%\right.$ condition) were pretreated with simvastatin $(25 \mu \mathrm{M})$ and increasing concentrations of cholesterol $(A)$ or mevalonic acid ( $C$ for $6 \mathrm{~h}$. After pretreatment, $A \beta_{25-35}(50 \mu \mathrm{m})$ and LPS $(1 \mu \mathrm{g} / \mathrm{ml})$ were added to the cells and incubated for $18 \mathrm{~h}$. Cell lysates were separated by Western blotting and probed with anti-IL-1 $\beta$ antibodies. Blots were stripped and reprobed with anti-Erk2 antibodies to monitor protein loading. $B, D$, Quantification of pooled experiments was performed for $A$ and $C$, respectively $(B, n=3 ; D, n=2)$. Veh, Vehicle.

A

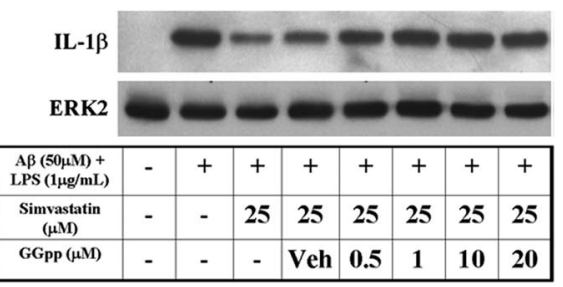

B

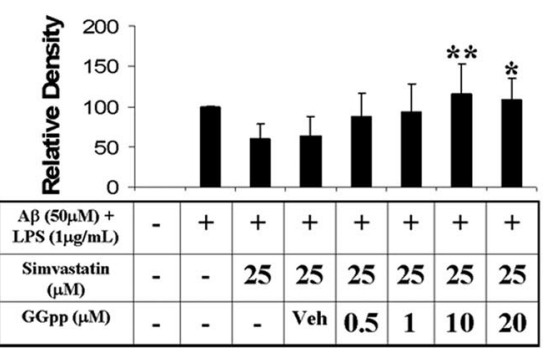

C

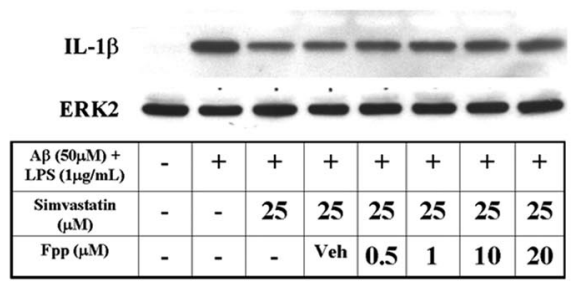

D

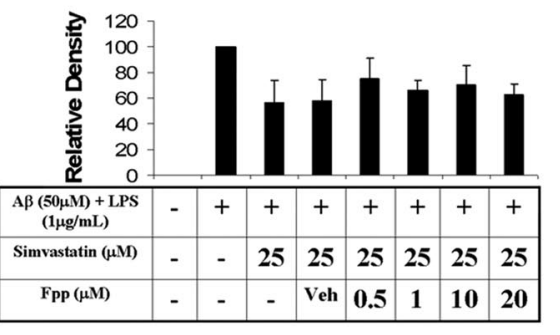

Figure 5. GGpp, but not Fpp, reverses the anti-inflammatory effects of statins. A, C, THP-1 cells ( $3 \times 10^{6} /$ condition) were pretreated with simvastatin $(25 \mu \mathrm{M})$ and increasing concentrations of $\mathrm{GGpp}(A)$ or $\mathrm{Fpp}(C)$ for $6 \mathrm{~h}$. After pretreatment, $A \beta_{25-35}(50$ $\mu \mathrm{M})$ and LPS $(1 \mu \mathrm{g} / \mathrm{ml})$ were added to the cells and incubated for $18 \mathrm{~h}$. Cell lysates were separated by Western blotting and probed with anti-IL-1 $\beta$ antibodies. Blots were stripped and reprobed with anti-Erk2 antibodies to monitor protein loading. $B, D$, Quantification of pooled experiments was performed for $A$ and $C$, respectively $\left(B, n=6 ;{ }^{*} p<0.05 ;{ }^{* *} p<0.01 ; D, n=2\right)$. Veh, Vehicle.

zymes responsible for the transfer of GGpp and Fpp to various proteins are geranylgeranyl transferase and farnesyl transferase, respectively. We used specific inhibitors of these enzymes, GTI286 and FTI-277, to test our hypothesis. THP-1 cells were pretreated with increasing concentration of GTI or FTI for $6 \mathrm{~h}$. We then followed our standard protocol for $A \beta / L P S$ exposure and IL-1 $\beta$ protein detection. Inhibition of the geranylgeranyl transferases resulted in a statistically significant, dose-dependent de- crease in IL- $1 \beta$ levels (Fig. $6 A, B$ ). Treatment with FTI had no effect on the levels of IL- $1 \beta$, suggesting that geranylgeranylated, but not farnesylated, proteins are involved in the anti-inflammatory actions of statins.

Inhibition of small G-protein function attenuates the production of IL- $1 \beta$ after $\mathrm{A} \boldsymbol{\beta}$ exposure

Isoprenylation of small G-proteins is critical for functional interaction with their effectors and subcellular localization. The Rho family of G-proteins, including Rho, $\mathrm{Rac}$, and $\mathrm{Cdc} 42$, are primarily isoprenylated by GGpp. Because the inhibition of GGpp transferase mimicked the antiinflammatory effects of statins, we hypothesized that the anti-inflammatory actions of the statins were a consequence of inhibition of Rho family GTPase function. We investigated the role of the Rho family of G-proteins in $A \beta$-stimulated IL- $1 \beta$ production by use of a specific inhibitor of this class of GTPases. Clostridium difficile Toxin A ADP-ribosylates G-proteins of the Rho family and renders them inactive. THP-1 cells were pretreated with increasing concentrations of Toxin A for $2 \mathrm{~h}$. The cells were then exposed to A $\beta /$ LPS for $6 \mathrm{~h}$, and IL- $1 \beta$ levels were determined (Fig. $7 A)$. Toxin A treatment greatly reduced the $A \beta /$ LPS-induced production of IL- $1 \beta$. The reduction in IL- $1 \beta$ was statistically significant at Toxin A concentrations as low as $10 \mathrm{~nm}$ (Fig. 7B). These experiments provide strong evidence that the antiinflammatory effects of statins are derived from their ability to suppress Rho family G-protein function by limiting GGpp levels and subsequently inhibiting isoprenylation.

\section{Discussion}

Our interest has focused on the role of inflammation in the $\mathrm{AD}$ brain and how the microglial-mediated proinflammatory response serves to exacerbate and drive the pathogenic processes leading to neuronal loss. Indeed, there is a substantial body of data documenting that microglial activation arises as a secondary consequence of the disease process and acts to facilitate amyloid production and deposition in the brain (Akiyama et al., 2000). Microglia are physically associated with $A \beta$ plaques and display a reactive phenotype, which is typified by increased cell surface expression of major histocompatibility complex class II (Rogers et al., 1988), CD11b, CD45, and immunoglobulin receptor Fc $\gamma$ RI (Akiyama and McGeer, 1990; McGeer and McGeer, 2003) along with other proinflammatory markers. Furthermore, microglia exposed to $\mathrm{A} \beta$ in the $\mathrm{AD}$ brain or in vitro release proinflammatory cytokines, including IL- $1 \beta$, IL- 6 , and TNF $\alpha$ (Xia et 
A

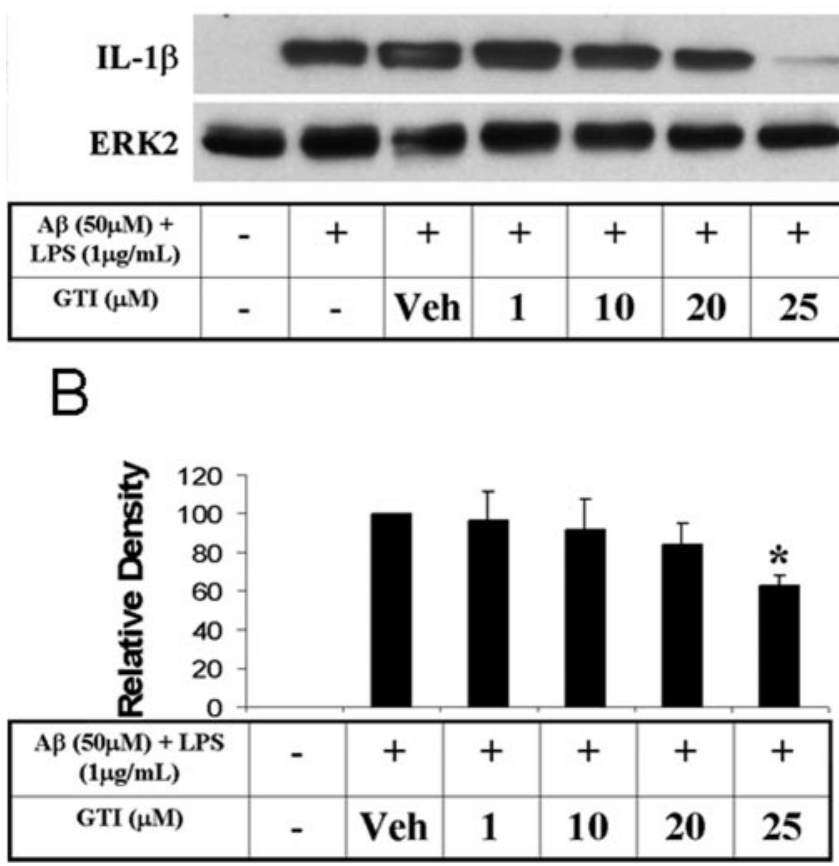

Figure 6. Inhibition of isoprenylation attenuates IL- $1 \beta$ induction after $A \beta$ stimulation. $A$, THP-1 cells $\left(3 \times 10^{6} /\right.$ condition) were pretreated with GTI for $6 \mathrm{~h}$. After pretreatment, $A \beta_{25-35}$ $(50 \mu \mathrm{m})$ and LPS $(1 \mu \mathrm{g} / \mathrm{ml})$ were added to the cells and incubated for $18 \mathrm{~h}$. Cell lysates were separated by Western blotting and probed with anti-IL-1 $\beta$ antibodies. Blots were stripped and reprobed with anti-Erk2 antibodies to monitor protein loading. $B$, Quantification of pooled experiments was performed $\left(n=2 ;{ }^{*} p<0.01\right.$ compared with $A \beta$ plus LPS). Veh, Vehicle.

al., 1998; Hesselgesser and Horuk, 1999; Akiyama et al., 2000; Grammas and Ovase, 2002; Haas et al., 2002; Smits et al., 2002). Inflammation acts to augment disease progression via its ability to stimulate neuronal A $\beta$ production (Blasko et al., 2001; Sastre et al., 2003; Sheng et al., 2003) and facilitate amyloid deposition (Qiao et al., 2001; Guo et al., 2002).

The conclusion that statin therapy may be beneficial to AD patients arose from three retrospective studies that demonstrated the positive effects of statins on the risk of developing AD. Wolozin et al. (2000) used a cross-sectional analysis design and reported that the risk of developing $\mathrm{AD}$ in patients receiving statin therapy was $60-73 \%$ lower than the general population. Subsequent retrospective studies and prospective clinical investigations strengthened this hypothesis (Jick et al., 2000; Rockwood et al., 2002; Caballero and Nahata, 2004).

The salutary effects of these drugs in $\mathrm{AD}$ have been interpreted to arise exclusively from their cholesterol-lowering effects. Indeed, there is a strong rationale linking statin use with reduced neuronal synthesis and secretion of amyloidogenic $\mathrm{A} \beta$ peptides. The epidemiological findings have found conceptual support in studies of animal models of $\mathrm{AD}$, demonstrating that highcholesterol diets result in exacerbation of $\mathrm{A} \beta$ deposition, an effect that is reversed by statin treatment (Fassbender et al., 2001; Refolo et al., 2001; Petanceska et al., 2002). Recent clinical investigations have demonstrated the ability of statins to modulate neuronal APP processing. Sjogren et al. (2003) observed reduced CSF $\alpha$ - and $\beta$-sAPP levels after 12 weeks of simvastatin therapy. Moreover, statin use has been correlated with a reduction in serum and CSF A $\beta$ levels and brain hydroxycholesterol levels (Buxbaum et al., 2002; Simons et al., 2002). It has been argued that the basis of these effects is the dependence of APP processing on
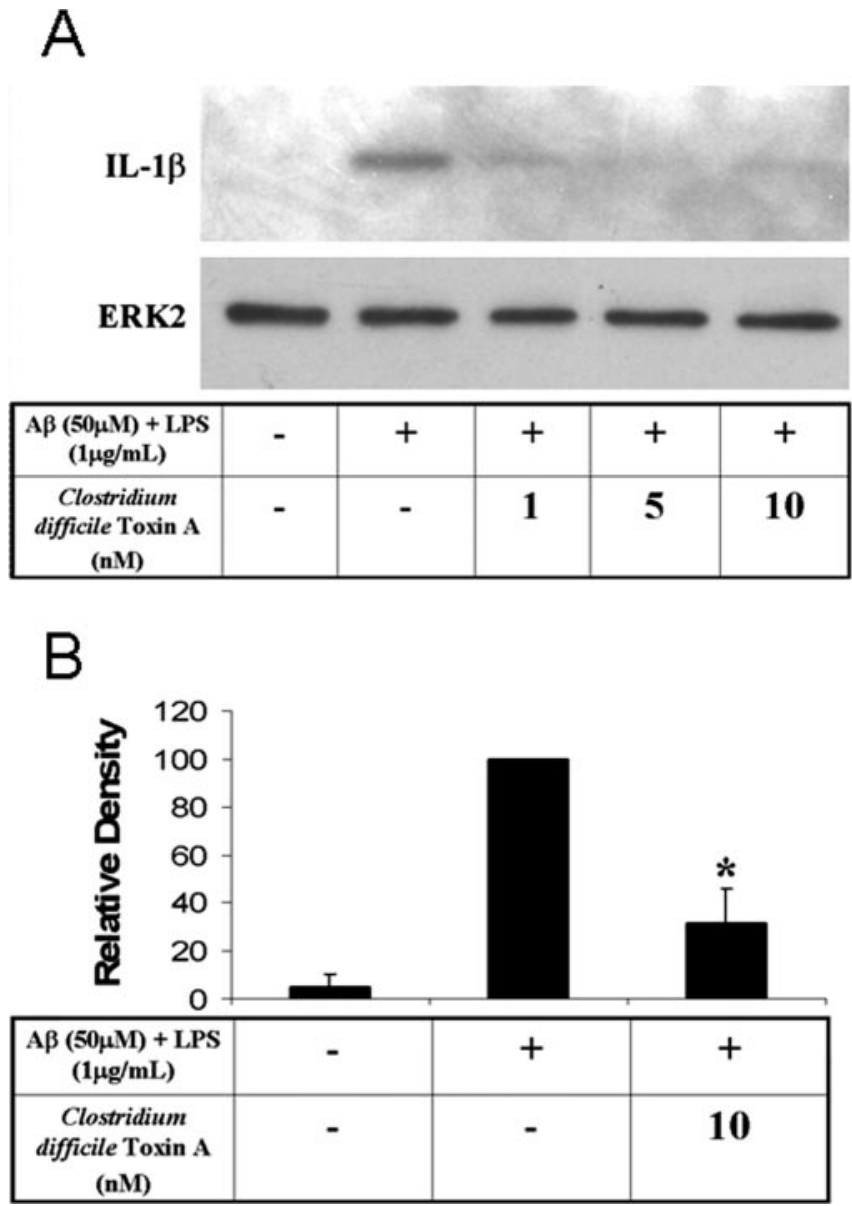

Figure 7. Inhibition of Rho-family small G-protein function attenuates IL- $1 \beta$ induction after A $\beta$ stimulation. $A$, THP-1 cells $\left(3 \times 10^{6} \%\right.$ condition) were pretreated with increasing concentrations of Clostridium difficile Toxin A for $2 \mathrm{~h}$. After pretreatment, the cells were incubated with $\mathrm{A} \beta_{25-35}(50 \mu \mathrm{M})$ and LPS $(1 \mu \mathrm{g} / \mathrm{ml})$ for an additional $6 \mathrm{~h}$. Cell lysates were separated by Western blotting and probed with anti-lL-1 $\beta$ antibodies. Blots were stripped and reprobed with anti-Erk2 antibodies to monitor protein loading. $B$, Quantification of pooled experiments was performed ( $n=2 ;{ }^{*} p<0.05$ compared with $\mathrm{A} \beta$ plus LPS). Veh, Vehicle.

neuronal membrane cholesterol content. In vitro experiments have shown that statin treatment and changes in cellular cholesterol levels can modulate $\mathrm{A} \beta$ homeostasis (Burns and Duff, 2002). The activities of all three secretases involved in APP processing are acutely sensitive to cholesterol levels (Bodovitz and Klein, 1996; Simons et al., 1998; Wahrle et al., 2002). Depletion of cholesterol from cellular membranes decreases the activities of $\beta$ and $\gamma$-secretases, whereas cholesterol supplementation can inhibit $\alpha$-secretase activity (Burns and Duff, 2002). It has been argued that reduction in membrane cholesterol would shunt APP processing into the $\alpha$-secretase pathway by decreasing the activity of the amyloidogenic secretases.

It has only recently been appreciated that HMG-CoA reductase inhibitors have anti-inflammatory effects that are independent of their ability to lower cholesterol levels. These observations were initially described by cardiovascular biologists who observed that statin-mediated protection from vascular accidents did not correlate with cholesterol reduction (Takemoto and Liao, 2001). Statin treatment has been shown to reduce levels of matrix metalloproteinase-9, TNF- $\alpha$, and monocyte chemotactic protein-1 (Bellosta et al., 1998; Grip et al., 2000, 2002; Wong et al., 2001) and decrease the activities of NF-kB, the NADPH oxidase complex, and iNOS (Pahan et al., 1997; Ortego et al., 1999; 
Delbosc et al., 2002; Zelvyte et al., 2002) in both vascular and myeloid-lineage cells. The efficacy of this class of drugs as antiinflammatory agents in the CNS has been convincingly demonstrated in a murine model of experimental allergic encephalitis (Youssef et al., 2002; Nath et al., 2004). Statins have also been shown to protect neurons from excitotoxic injury (Zacco et al., 2003).

In the present study, we have shown that A $\beta /$ LPS stimulation results in the production of a number of inflammatory markers, including IL-1 $\beta$, iNOS, and reactive nitrogen and oxygen species. Importantly, statin treatment attenuates these $\mathrm{A} \beta$-mediated proinflammatory responses. The statin-mediated suppression of inflammation is independent of cholesterol reduction but dependent on proximal elements of the cholesterol biosynthetic pathway required for GGpp-mediated isoprenylation of Rho family members. The anti-inflammatory actions of the statins arise from lower levels of functionally active, lipid-modified members of the Rho family of small G-proteins, which are critical regulators of inflammatory signaling pathways. The isoprenyl group is transferred to the $\mathrm{C}$ terminus of the G-protein, and this modification is required for transfer and localization to the plasma membrane (Zhang and Casey, 1996). The lipid moiety intercalates into the membrane, allowing stable localization of the protein at the inner face of the membrane and access to its downstream effectors. Isoprenylation is also required for retention of Rac and Rho in the cytoplasm in resting cells through the interaction of the lipid moiety with Rho-GDP dissociation inhibitor (GDI), which serves as a cytoplasmic anchor for the G-proteins. After stimulation, Rho-GDI participates in the ligand-stimulated translocation of the G-protein to the membrane and facilitates its conversion into an active conformation. Inhibition of protein isoprenylation or block of Rho family G-protein action resulted in inhibition of inflammatory gene expression in a manner identical to that of the statins.

The observation that statins may significantly reduce AD risk has been interpreted previously to be exclusively the result of their cholesterol-lowering actions. The secretases involved with APP processing are sensitive to membrane cholesterol levels, and it was thought disease protection could be explained by their ability to prevent $\mathrm{A} \beta$ production. One of the principal conclusions of the present study is that statins exert potent antiinflammatory effects, which adds a new dimension to the actions of statins in the $\mathrm{AD}$ brain. There is a strong rationale for why anti-inflammatory therapies may be efficacious in the treatment of $\mathrm{AD}$. We argue that the clinical efficacy of these drugs is attributable to their pleiotropic actions, acting in a cholesteroldependent manner to suppress neuronal $\mathrm{A} \beta$ synthesis and in a cholesterol-independent manner to inhibit microglial proinflammatory reactions.

The recognition that the statins may have multiple independent actions on $\mathrm{AD}$ pathophysiology parallels the recent observations regarding the mechanisms of action of NSAIDs in the disease. Epidemiological studies have demonstrated that chronic use of NSAIDs, like the statins, reduces the risk of developing AD by $\sim 70 \%$ (Etminan et al., 2003). Recent observations of the pleiotropic actions of NSAIDs have forced a substantial reevaluation of how these drugs act to affect AD. NSAIDs, traditionally administered to attenuate inflammatory reactions, have been shown to suppress microglia-mediated inflammation and subsequent neuronal death. Indeed, ibuprofen treatment suppresses microglial activation in animal models of AD (Lim et al., 2000; Yan et al., 2003) and reduces the number of plaque-associated microglia in the AD brain (Mackenzie and Munoz, 1998). Importantly, it has recently been reported that a subset of NSAIDs inhibits the synthesis of the amyloidgenic $\mathrm{A} \beta_{1-42}$ by direct interaction with the $\gamma$-secretase (Weggen et al., 2001, 2003) or by inhibiting RhoA-dependent signaling events (Zhou et al., 2003). Together, these findings suggest that both classes of drugs exhibit pleiotropic actions that may underlie their efficacy in reducing $\mathrm{AD}$ risk. Statins and NSAIDs share a common general mechanism to alter AD pathogenesis in which APP processing is downregulated in neurons and inflammatory responses are suppressed in microglia. The effects of statin therapy on AD risk and progression are now being evaluated in large-scale clinical trials. The present study offers a more complex view of the mechanism of action of these drugs.

\section{References}

Akiyama H, McGeer PL (1990) Brain microglia constitutively express beta-2 integrins. J Neuroimmunol 30:81-93.

Akiyama H, Barger S, Barnum S, Bradt B, Bauer J, Cole GM, Cooper NR, Eikelenboom P, Emmerling M, Fiebich BL, Finch CE, Frautschy S, Griffin WS, Hampel H, Hull M, Landreth G, Lue L, Mrak R, Mackenzie IR, McGeer PL, et al. (2000) Inflammation and Alzheimer's disease. Neurobiol Aging 21:383-421.

Bamberger ME, Harris ME, McDonald DR, Husemann J, Landreth GE (2003) A cell surface receptor complex for fibrillar $\beta$-amyloid mediates microglial activation. J Neurosci 23:2665-2674.

Bellosta S, Via D, Canavesi M, Pfister P, Fumagalli R, Paoletti R, Bernini F (1998) HMG-CoA reductase inhibitors reduce MMP-9 secretion by macrophages. Arterioscler Thromb Vasc Biol 18:1671-1678.

Blasko I, Apochal A, Boeck G, Hartmann T, Grubeck-Loebenstein B, Ransmayr G (2001) Ibuprofen decreases cytokine-induced amyloid beta production in neuronal cells. Neurobiol Dis 8:1094-1101.

Bodovitz S, Klein WL (1996) Cholesterol modulates alpha-secretase cleavage of amyloid precursor protein. J Biol Chem 271:4436-4440.

Bradford MM (1976) A rapid and sensitive method for the quantitation of microgram quantities of protein utilizing the principle of protein-dye binding. Anal Biochem 72:248-254.

Burns M, Duff K (2002) Cholesterol in Alzheimer's disease and tauopathy. Ann NY Acad Sci 977:367-375.

Buxbaum JD, Cullen EI, Friedhoff LT (2002) Pharmacological concentrations of the HMG-CoA reductase inhibitor lovastatin decrease the formation of the Alzheimer beta-amyloid peptide in vitro and in patients. Front Biosci 7:a50-a59.

Caballero J, Nahata M (2004) Do statins slow down Alzheimer's disease? A review. J Clin Pharm Ther 29:209-213.

Combs CK, Johnson DE, Cannady SB, Lehman TM, Landreth GE (1999) Identification of microglial signal transduction pathways mediating a neurotoxic response to amyloidogenic fragments of $\beta$-amyloid and prion proteins. J Neurosci 19:928-939.

Combs CK, Johnson DE, Karlo JC, Cannady SB, Landreth GE (2000) Inflammatory mechanisms in Alzheimer's disease: inhibition of $\beta$-amyloidstimulated proinflammatory responses and neurotoxicity by PPAR $\gamma$ agonists. J Neurosci 20:558-567.

Combs CK, Bates P, Karlo JC, Landreth GE (2001a) Regulation of betaamyloid stimulated proinflammatory responses by peroxisome proliferator-activated receptor alpha. Neurochem Int 39:449-457.

Combs CK, Karlo JC, Kao SC, Landreth GE (2001b) $\beta$-Amyloid stimulation of microglia and monocytes results in TNF $\alpha$-dependent expression of inducible nitric oxide synthase and neuronal apoptosis. J Neurosci 21:1179-1188.

Cordy JM, Hussain I, Dingwall C, Hooper NM, Turner AJ (2003) Exclusively targeting beta-secretase to lipid rafts by GPI-anchor addition upregulates beta-site processing of the amyloid precursor protein. Proc Natl Acad Sci USA 100:11735-11740.

Delbosc S, Morena M, Djouad F, Ledoucen C, Descomps B, Cristol JP (2002) Statins, 3-hydroxy-3-methylglutaryl coenzyme A reductase inhibitors, are able to reduce superoxide anion production by NADPH oxidase in THP-1-derived monocytes. J Cardiovasc Pharmacol 40:611-617.

Endo A (1992) The discovery and development of HMG-CoA reductase inhibitors. J Lipid Res 33:1569-1582.

Etminan M, Gill S, Samii A (2003) Effect of non-steroidal antiinflammatory drugs on risk of Alzheimer's disease: systematic review and meta-analysis of observational studies. BMJ 327:128. 
Fassbender K, Simons M, Bergmann C, Stroick M, Lutjohann D, Keller P, Runz H, Kuhl S, Bertsch T, von Bergmann K, Hennerici M, Beyreuther K, Hartmann T (2001) Simvastatin strongly reduces levels of Alzheimer's disease beta-amyloid peptides Abeta 42 and Abeta 40 in vitro and in vivo. Proc Natl Acad Sci USA 98:5856-5861.

Giovannini MG, Scali C, Prosperi C, Bellucci A, Vannucchi MG, Rosi S, Pepeu G, Casamenti F (2002) Beta-amyloid-induced inflammation and cholinergic hypofunction in the rat brain in vivo: involvement of the p38MAPK pathway. Neurobiol Dis 11:257-274.

Grammas P, Ovase R (2002) Cerebrovascular transforming growth factorbeta contributes to inflammation in the Alzheimer's disease brain. Am J Pathol 160:1583-1587.

Green LC, Wagner DA, Glogowski J, Skipper PL, Wishnok JS, Tannenbaum SR (1982) Analysis of nitrate, nitrite, and [15N]nitrate in biological fluids. Anal Biochem 126:131-138.

Grip O, Janciauskiene S, Lindgren S (2000) Pravastatin down-regulates inflammatory mediators in human monocytes in vitro. Eur J Pharmacol 410:83-92.

Grip O, Janciauskiene S, Lindgren S (2002) Atorvastatin activates PPARgamma and attenuates the inflammatory response in human monocytes. Inflamm Res 51:58-62.

Guo JT, Yu J, Grass D, de Beer FC, Kindy MS (2002) Inflammationdependent cerebral deposition of serum amyloid a protein in a mouse model of amyloidosis. J Neurosci 22:5900-5909.

Haas J, Storch-Hagenlocher B, Biessmann A, Wildemann B (2002) Inducible nitric oxide synthase and argininosuccinate synthetase: co-induction in brain tissue of patients with Alzheimer's dementia and following stimulation with beta-amyloid 1-42 in vitro. Neurosci Lett 322:121-125.

Hesselgesser J, Horuk R (1999) Chemokine and chemokine receptor expression in the central nervous system. J Neurovirol 5:13-26.

Jick H, Zornberg GL, Jick SS, Seshadri S, Drachman DA (2000) Statins and the risk of dementia. Lancet 356:1627-1631.

Kojro E, Gimpl G, Lammich S, Marz W, Fahrenholz F (2001) Low cholesterol stimulates the nonamyloidogenic pathway by its effect on the alphasecretase ADAM 10. Proc Natl Acad Sci USA 98:5815-5820.

Liao JK (2002) Isoprenoids as mediators of the biological effects of statins. J Clin Invest 110:285-288.

Liao JK, Laufs U (2004) Pleiotropic effects of statins. Annu Rev Pharmacol Toxicol, in press.

Lim GP, Yang F, Chu T, Chen P, Beech W, Teter B, Tran T, Ubeda O, Ashe KH, Frautschy SA, Cole GM (2000) Ibuprofen suppresses plaque pathology and inflammation in a mouse model for Alzheimer's disease. J Neurosci 20:5709-5714.

Mackenzie IR, Munoz DG (1998) Nonsteroidal anti-inflammatory drug use and Alzheimer-type pathology in aging. Neurology 50:986-990.

Masliah E, Mallory M, Hansen L, Alford M, Albright T, Terry R, Shapiro P, Sundsmo M, Saitoh T (1991) Immunoreactivity of CD45, a protein phosphotyrosine phosphatase, in Alzheimer's disease. Acta Neuropathol (Berl) 83:12-20.

McDonald DR, Brunden KR, Landreth GE (1997) Amyloid fibrils activate tyrosine kinase-dependent signaling and superoxide production in microglia. J Neurosci 17:2284-2294.

McGeer EG, McGeer PL (2003) Inflammatory processes in Alzheimer's disease. Prog Neuropsychopharmacol Biol Psychiatry 27:741-749.

Nath N, Giri S, Prasad R, Singh AK, Singh I (2004) Potential targets of 3-hydroxy-3-methylglutaryl coenzyme A reductase inhibitor for multiple sclerosis therapy. J Immunol 172:1273-1286.

Ortego M, Bustos C, Hernandez-Presa MA, Tunon J, Diaz C, Hernandez G, Egido J (1999) Atorvastatin reduces NF-kappaB activation and chemokine expression in vascular smooth muscle cells and mononuclear cells. Atherosclerosis 147:253-261.

Pahan K, Sheikh FG, Namboodiri AM, Singh I (1997) Lovastatin and phenylacetate inhibit the induction of nitric oxide synthase and cytokines in rat primary astrocytes, microglia, and macrophages. J Clin Invest 100:2671-2679.

Parvathy S, Ehrlich M, Pedrini S, Diaz N, Refolo L, Buxbaum JD, Bogush A, Petanceska S, Gandy S (2004) Atorvastatin-induced activation of Alzheimer's alpha secretase is resistant to standard inhibitors of protein phosphorylation-regulated ectodomain shedding. J Neurochem 90:1005-1010.

Peress NS, Fleit HB, Perillo E, Kuljis R, Pezzullo C (1993) Identification of Fc gamma RI, II and III on normal human brain ramified microglia and on microglia in senile plaques in Alzheimer's disease. J Neuroimmunol 48:71-79.

Petanceska SS, DeRosa S, Olm V, Diaz N, Sharma A, Thomas-Bryant T, Duff K, Pappolla M, Refolo LM (2002) Statin therapy for Alzheimer's disease: will it work? J Mol Neurosci 19:155-161.

Puglielli L, Tanzi RE, Kovacs DM (2003) Alzheimer's disease: the cholesterol connection. Nat Neurosci 6:345-351.

Qiao X, Cummins DJ, Paul SM (2001) Neuroinflammation-induced acceleration of amyloid deposition in the APPV717F transgenic mouse. Eur J Neurosci 14:474-482.

Refolo LM, Pappolla MA, LaFrancois J, Malester B, Schmidt SD, ThomasBryant T, Tint GS, Wang R, Mercken M, Petanceska SS, Duff KE (2001) A cholesterol-lowering drug reduces beta-amyloid pathology in a transgenic mouse model of Alzheimer's disease. Neurobiol Dis $8: 890-899$.

Rockwood K, Kirkland S, Hogan DB, MacKnight C, Merry H, Verreault R, Wolfson C, McDowell I (2002) Use of lipid-lowering agents, indication bias, and the risk of dementia in community-dwelling elderly people. Arch Neurol 59:223-227.

Rogers J, Luber-Narod J, Styren SD, Civin WH (1988) Expression of immune system-associated antigens by cells of the human central nervous system: relationship to the pathology of Alzheimer's disease. Neurobiol Aging 9:339-349.

Sastre M, Dewachter I, Landreth GE, Willson TM, Klockgether T, van Leuven F, Heneka MT (2003) Nonsteroidal anti-inflammatory drugs and peroxisome proliferator-activated receptor- $\gamma$ agonists modulate immunostimulated processing of amyloid precursor protein through regulation of beta-secretase. J Neurosci 23:9796-9804.

Sheng JG, Bora SH, Xu G, Borchelt DR, Price DL, Koliatsos VE (2003) Lipopolysaccharide-induced-neuroinflammation increases intracellular accumulation of amyloid precursor protein and amyloid beta peptide in APPswe transgenic mice. Neurobiol Dis 14:133-145.

Simons M, Keller P, De Strooper B, Beyreuther K, Dotti CG, Simons K (1998) Cholesterol depletion inhibits the generation of beta-amyloid in hippocampal neurons. Proc Natl Acad Sci USA 95:6460-6464.

Simons M, Schwarzler F, Lutjohann D, von Bergmann K, Beyreuther K, Dichgans J, Wormstall H, Hartmann T, Schulz JB (2002) Treatment with simvastatin in normocholesterolemic patients with Alzheimer's disease: a 26-week randomized, placebo-controlled, double-blind trial. Ann Neurol 52:346-350.

Sjogren M, Gustafsson K, Syversen S, Olsson A, Edman A, Davidsson P, Wallin A, Blennow K (2003) Treatment with simvastatin in patients with Alzheimer's disease lowers both alpha- and beta-cleaved amyloid precursor protein. Dement Geriatr Cogn Disord 16:25-30.

Smits HA, Rijsmus A, van Loon JH, Wat JW, Verhoef J, Boven LA, Nottet HS (2002) Amyloid-beta-induced chemokine production in primary human macrophages and astrocytes. J Neuroimmunol 127:160-168.

Takemoto M, Liao JK (2001) Pleiotropic effects of 3-hydroxy-3methylglutaryl coenzyme a reductase inhibitors. Arterioscler Thromb Vasc Biol 21:1712-1719.

Tobert JA (2003) Lovastatin and beyond: the history of the HMG-CoA reductase inhibitors. Nat Rev Drug Discov 2:517-526.

Wahrle S, Das P, Nyborg AC, McLendon C, Shoji M, Kawarabayashi T, Younkin LH, Younkin SG, Golde TE (2002) Cholesterol-dependent gamma-secretase activity in buoyant cholesterol-rich membrane microdomains. Neurobiol Dis 9:11-23.

Weggen S, Eriksen JL, Das P, Sagi SA, Wang R, Pietrzik CU, Findlay KA, Smith TE, Murphy MP, Bulter T, Kang DE, Marquez-Sterling N, Golde TE, Koo EH (2001) A subset of NSAIDs lower amyloidogenic Abeta42 independently of cyclooxygenase activity. Nature 414:212-216.

Weggen S, Eriksen JL, Sagi SA, Pietrzik CU, Ozols V, Fauq A, Golde TE, Koo EH (2003) Evidence that nonsteroidal anti-inflammatory drugs decrease amyloid beta 42 production by direct modulation of gammasecretase activity. J Biol Chem 278:31831-31837.

Weldon DT, Rogers SD, Ghilardi JR, Finke MP, Cleary JP, O’Hare E, Esler WP, Maggio JE, Mantyh PW (1998) Fibrillar $\beta$-amyloid induces microglial phagocytosis, expression of inducible nitric oxide synthase, and loss of a select population of neurons in the rat CNS in vivo. J Neurosci 18:2161-2173.

Wolozin B (2002) Cholesterol and Alzheimer's disease. Biochem Soc Trans 30:525-529. 
Wolozin B, Kellman W, Ruosseau P, Celesia GG, Siegel G (2000) Decreased prevalence of Alzheimer disease associated with 3-hydroxy-3-methyglutaryl coenzyme A reductase inhibitors. Arch Neurol 57:1439-1443.

Wong B, Lumma WC, Smith AM, Sisko JT, Wright SD, Cai TQ (2001) Statins suppress THP-1 cell migration and secretion of matrix metalloproteinase 9 by inhibiting geranylgeranylation. J Leukoc Biol 69:959-962.

Xia MQ, Qin SX, Wu LJ, Mackay CR, Hyman BT (1998) Immunohistochemical study of the beta-chemokine receptors CCR3 and CCR5 and their ligands in normal and Alzheimer's disease brains. Am J Pathol 153:31-37.

Yan Q, Zhang J, Liu H, Babu-Khan S, Vassar R, Biere AL, Citron M, Landreth G (2003) Anti-inflammatory drug therapy alters $\beta$-amyloid processing and deposition in an animal model of Alzheimer's disease. J Neurosci 23:7504-7509.

Yates SL, Burgess LH, Kocsis-Angle J, Antal JM, Dority MD, Embury PB, Piotrkowski AM, Brunden KR (2000) Amyloid beta and amylin fibrils induce increases in proinflammatory cytokine and chemokine production by THP-1 cells and murine microglia. J Neurochem 74:1017-1025.
Youssef S, Stuve O, Patarroyo JC, Ruiz PJ, Radosevich JL, Hur EM, Bravo M, Mitchell DJ, Sobel RA, Steinman L, Zamvil SS (2002) The HMG-CoA reductase inhibitor, atorvastatin, promotes a Th2 bias and reverses paralysis in central nervous system autoimmune disease. Nature 420:78-84.

Zacco A, Togo J, Spence K, Ellis A, Lloyd D, Furlong S, Piser T (2003) 3-Hydroxy-3-methylglutaryl coenzyme A reductase inhibitors protect cortical neurons from excitotoxicity. J Neurosci 23:11104-11111.

Zelvyte I, Dominaitiene R, Crisby M, Janciauskiene S (2002) Modulation of inflammatory mediators and PPARgamma and NFkappaB expression by pravastatin in response to lipoproteins in human monocytes in vitro. Pharmacol Res 45:147-154.

Zhang FL, Casey PJ (1996) Protein prenylation: molecular mechanisms and functional consequences. Annu Rev Biochem 65:241-269.

Zhou Y, Su Y, Li B, Liu F, Ryder JW, Wu X, Gonzalez-DeWhitt PA, Gelfanova V, Hale JE, May PC, Paul SM, Ni B (2003) Nonsteroidal antiinflammatory drugs can lower amyloidogenic Abeta 42 by inhibiting Rho. Science 302:1215-1217. 